Contents lists available at Џournal IICET

JPPI (Jurnal Penelitian Pendidikan Indonesia)

ISSN: 2502-8103 (Print) ISSN: 2477-8524 (Electronic)

\title{
Teaching game for understanding model: increasing motivation and students' physical fitness
}

\author{
Syamsuar Syamsuar ${ }^{1}$, Zelhendri Zen ${ }^{1}$ \\ ${ }^{1}$ Universitas Negeri Padang, Indonesia
}

\begin{tabular}{l} 
Article Info \\
\hline Article history: \\
Received Mar $27^{\text {th }}, 2021$ \\
Revised Apr $03^{\text {rd }}, 2021$ \\
Accepted May $09^{\text {th }}, 2021$ \\
\hline
\end{tabular}

\section{Keyword:}

Teaching game

Understanding model,

Motivation

Physical fitness

\begin{abstract}
This study aims to analyze the effect of Teaching Game for Understanding (TGfU) in increasing the students' motivation and physical fitness. TGfU is a training concept of sport based on game. It is not only have meaning as strengthening educational praxis in fields of sport-game separately, but rather to develop an educational approach to the problems solving in tactical strategy in a competition of the sport-game, and also about attitude, motivation. Method of this study uses classroom action research. The subject of the research is 25 primary students' in Sungai Sariak Padang Pariaman district. The results of the study reported that method of TGfU can increase students' motivation and physical fitness especially in the second cycle of teaching and learning in the field. For sport teacher is advised to use this model in order to improve students' participation, motivation, tactical cognitive and strategy and sport achievement of their physical fitness, especially for the subject matter of sport required the game approach.
\end{abstract}

C 2021 The Authors. Published by IICET.

This is an open access article under the CC BY-NC-SA license

(https://creativecommons.org/licenses/by-nc-sa/4.0

\section{Corresponding Author:}

Syamsuar Syamsuar

Universitas Negeri Padang

Email: syamsuar@gmail.com

\section{Introduction}

Physical education taught in schools has an important role in providing opportunities for students to be directly involved in various learning experiences (Chiva-Bartoll, Maravé-Vivas, Salvador-García, \& ValverdeEsteve, 2021; Ní Chróinín \& Cosgrave, 2013). The learning experience starts from physical activities, cooperation and physical fitness which carried out systematically. Hellison states that physical education has the potential to develop values and social responsibilities and attitudes which can be developed through the following learning models: Learning the level of self-control, this level describes students being able to control their behavior, but not participating in all learning activities and the level of students' involvement. At this level, students are stated to have actively participated in lessons from the beginning of learning to achieving lesson objectives.Learning to be socially responsible, this level contains building students' social responsibility independently. At this level students can learn effectively without having to be initiated directly by the teacher. Learning social responsibility of students towards others, at this level students are already interested in encouraging and helping their friends to learn without having to be instructed by the teacher to do so (ChivaBartoll \& Fernández-Rio, 2021; Hellison, 2010).

Physical education is a learning process to move and learn through motion, here it is clear that students are taught to learn the basic movements of the human body, namely walking, running, throwing, catching, creeping, crawling, jumping and other forms of basic movements (Karisman, 2021; Nyberg \& Larsson, 2014). 
Therefore, physical education has intellectual performance which can create enthusiasm for someone to cooperate, work effectively and be integrated with all efforts to achieve good learning outcomes. To implement effective teaching in the sports education, appropriate teaching models are needed for cognitive, affective and psychomotor skills outcomes. Educational development systems should be selected from the most urgent and central educational activities that will serve as the basic model for selection that leads to physical and students' intellectuals (Luguetti \& McDonald, 2021).The sports learning model in the form of a game is very important to be developed by physical education teachers to improve children's physical fitness, teaching with a playful approach is inherent in the practice of teaching physical education in schools. Because playing practice is an interaction between students who they enjoy doing the learning process and sports training to improve physical fitness. However, the concept of the game method is difficult to find in the physical education literature (Roberts, Newcombe, \& Davids, 2019; Stork \& Sanders, 2008).

Sports learning should be carried out using a game approach. One of these models is the Teaching Game for Understanding (TGfU) approach (Gil-Arias, Harvey, Cárceles, Práxedes, \& Del Villar, 2017). This approach may increase students' physical cognitive and motivation so that a pleasant sports learning atmosphere is built (Jarrett, Eloi, \& Harvey, 2014). Williams, DJ, García Bengoechea, E. \& Strean, WB, stated that the use of the TGfU model in Physical Education is very appropriate and in accordance with the sports learning model for elementary school children (Holt, Strean, \& Bengoechea, 2002). Physical education not only develops physical and cognitive skills but also emphasizes affective influences, attitudes, behavior and motivation of students in participating of learning and training (Heemsoth, Boe, Bükers, \& Krieger, 2020). .TGfU can clearly give a positive impression on children's physical activity experiences, which can increase students' intrinsic motivation to take an active role in all activities and physical activities taught by teachers both in class and in the field and at the same time increase students' proficiency in playing rounders, especially skills in hitting the ball, throwing the ball, running the ball, catching the ball and other physical dexterity (Alcalá \& Garijo, 2017; García-Castejón et al., 2021).

The intensive TGfU learning model will have a major influence on improving the physical fitness of elementary school students in Padang Pariaman Regency. Using the TGfU model in learning to play rounders can increase students' motivation to take part in learning and physical exercise and also improve their physical fitness. In addition to improving physical fitness, this TGfU model can also improve students' cognitive abilities, especially in developing game tactics and managing match strategies in rounders (López-Pastor, Kirk, Lorente-Catalán, MacPhail, \& Macdonald, 2013). Teaching games for understanding is a tactic-based sports learning approach to improve children's physical fitness which is expected to increase their active participation and increase their learning outcomes (MacPhail, Kirk, \& Griffin, 2008). Teaching games for understanding learning model is not a new concept, for sports teachers, but has become a familiar model used by sports teachers in elementary schools. The key problem in TGfU research is the difference between an engineering approach and a tactical approach. This highlights the problem of differentiating tactical learning from technical learning (Samodra, 2021; Sudirman, 2021). Teaching a game from the TGfU is a combination of tactical and technical understanding with skill development rather than focusing on one aspect alone. This implies the application of a tactical approach to skills in game teaching (Dimas, Galway, \& Gammage, 2021; Hopper \& Kruisselbrink, 2002).

In addition to improving physical fitness, the TGfU model can also be applied to increase student motivation. Motivation is energy changes in a person characterized by the emergence of "feelings" and preceded by a response to a goal (García-Castejón, et al., 2021; Gil-Arias et al., 2021). There are three important elements in motivation (Ferkins, Shilbury, \& McDonald, 2005), namely 1) motivation initiates energy changes in each individual human being, 2) motivation stimulates the emergence of a person's feelings and affection for an activity and 3) motivation creates a response to take positive action in achieving goals. Related to this research, the motivation to be investigated is the motivation that appears in students covering these three aspects, namely giving birth to positive energy in the form of stimulation of high interest in learning, a sense of liking and loving sports activities so that it makes them more diligent and earnestly doing activities. Sports and getting more motivated give birth to positive actions in the form of increased enthusiasm for learning and training in students which is quite high.

Previous research about the integrated learning model as the best practice on physical fitness (Reflianto \& Syamsuar, 2017). This research shows that there is a significant difference between motivation and physical fitness, where the TGfU model is proven to increase motivation and physical fitness of students in a better direction. It is known that the implementation of the TGfU model is able to increase interest, diligence and sincerity, a strong sense of curiosity and enthusiasm for learning and training in students. This is achieved because the TGfU model can certainly direct students to focus on one learning goal, namely practicing and competing in a sports game.Based on these findings, the authors were invited to see the effectiveness of the 
TGfU model further in the classroom action research approach to what extent the role of the teacher succeeded in applying the TGfU model to be effective in increasing students' motivation to learn and practice and at the same time increasing their physical fitness as measured by using the Indonesian Physical Fitness Test (IPFT). This study aims to analyze and examine the effect of Teaching Game for Understanding (TGfU) in increasing the students' motivation and physical fitness.

\section{Method}

Method of this research is classroom action research (Kunlasomboon, Wongwanich, \& Suwanmonkha, 2015). This research method is very appropriate to use because it is considered in accordance with the problems that will be revealed by the researcher, namely the lack of student motivation which results in decreased learning outcomes and student physical fitness even after participating in games and physical exercise. The subject of the research is 25 primary students' in Sungai Sariak Padang Pariaman district. The low ability of students in developing strategies and tactics in a sports game using the Teaching Game for Understanding model in the rounders game is the main reason for the need to do this research and at the same time look for other alternatives to take action to improve students' motivation and physical fitness through TGfU learning.The design of this study includes four stages, namely: planning, action, observing, and reflecting . Reflection is carried out to determine the extent of the teaching results that have been carried out by researchers so that improvements can be made in the next cycle if needed. Learning evaluation is carried out to assess student progress in understanding roundes games and achieving optimal learning outcomes. To achieve this, students' understanding and physical fitness tests as well as observations were carried out. The final evaluation was carried out to determine student achievement in mastery of the rounderss game material using the TGfU learning model by means of written tests and practical tests. Data analysis was performed every time after giving an action. The data analysis technique used is the flow model proposed by (Huberman \& Miles, 2002) which includes reducing data, presenting data, and drawing conclusions and verification. The criteria for the success of the action include two components, namely: process success criteria and learning outcome success criteria.

\section{Results and Discussions}

\section{First Cycle of Teaching}

The initial test was intended to determine students' understanding of the rounders game material using the TGfU learning model as a prerequisite and for the formation of study groups and exercises. Meanwhile, for the material specified in the syllabus, there is no pre-test because the material only continues the first cycle. The initial test was followed by all 25 students of the research subjects. The initial test material includes students' perceptions and basic knowledge about the rounders game technique and its effect on physical fitness. The atmosphere of the initial test was calm. All students take rounders game training and at the end of the session take a student physical fitness test.

In the next Rounders Game exercise, the researcher explains the techniques of catching the ball, throwing the ball, passing the ball, hitting the ball and running techniques and avoiding ball hits. Learning is given on a TGfU basis so that students develop tactical abilities to develop strategies for playing rounders in a match. In rounders match practice, students are divided into two groups that will compete to win the rounders game competition. Each group has a group leader. In accordance with the game steps that have been prepared, the researcher explains the duties and responsibilities of group members in each game. Each member of each group gets a physical exercise task in the form of running 40 meters, pull up, sit up 30 seconds, Upright Jumping and run 600 meters.

In the rounders game, students are given worksheets, each member of each group works together, each member of each group must understand the rounders game material given, Each group prepares 1 or 2 representatives to report the results of the exercise and the rest helps record and measure the value of physical fitness of his friends using the Indonesian Physical Fitness Test (IPFT).Meanwhile the teacher also measures the motivation of students who are involved in classroom action using a questionnaire. Students were asked to fill out a questionnaire about their motivation to participate in a whole series of learning activities and rounders ball game training using the TGfU model. At the end of the exercise each group writes a conclusion on the back of the last page of their worksheets. The estimated time in its implementation is in accordance with the plan, namely \pm 90 minutes.

Furthermore, during the discussion activities there were some students who still had difficulty filling in the worksheets related to understanding the rounders game, even though they had received explanations from 
their group friends. Therefore, researchers try to provide individual guidance to all students who experience these difficulties. After receiving the explanation, the students said they understood and immediately continued practicing the rounders ball game with their group friends and did the Physical Fitness Test and completed questions about the rounders game rules in the student activities sheets.

The following are the findings of students' motivation for learning rounders games using the TGfU model in the first cycle.

Table 1. Student Motivation in the First Cycle of Teaching by using TGfU learning model

\begin{tabular}{|c|c|c|c|c|c|}
\hline \multirow[t]{2}{*}{ Motivation to learn } & \multicolumn{3}{|c|}{ Level } & \multirow[t]{2}{*}{ Average } & \multirow[t]{2}{*}{ SD } \\
\hline & $\begin{array}{c}\text { Low } \\
(0-2.5)\end{array}$ & $\begin{array}{c}\text { Moderate } \\
(2.6-3.9) \\
\end{array}$ & $\begin{array}{r}\text { High } \\
(4.0-5.0) \\
\end{array}$ & & \\
\hline Interest to learn & $20(80.0 \%)$ & $5(20.0 \%)$ & - & 1.6 & 3.49 \\
\hline Diligent and serious & $22(88.0 \%)$ & $3(12.0 \%)$ & - & 1.4 & 3.54 \\
\hline Strong curiosity & $21(84.0 \%)$ & $4(16.0 \%)$ & - & 1.5 & 2.68 \\
\hline $\begin{array}{l}\text { The spirit of learning and } \\
\text { practicing }\end{array}$ & $23(92.0 \%)$ & $2(8.0 \%)$ & - & 1.4 & 2.21 \\
\hline Average & & & & 1.48 & 2.98 \\
\hline
\end{tabular}

Based on Table 1, it shows that the level of primary students' motivation Sungai Sariak Padang Pariaman district is 1.6 with a standard deviation of 3.49, of which of the 25 students, 20 of them (68.0\%) have low motivation and 5 of them $(20.0 \%)$ have moderate motivation. Diligence and sincerity with a mean value of 1.4 and a standard deviation of 3.54 obtained from 22 students $(88.0 \%)$ with low motivation and 3 students $(12.0 \%)$ with moderate motivation. Meanwhile, the average element of strong curiosity was 1.5 with a standard deviation of 2.68 consisting of 21 students $(84.0 \%)$ low motivation and 4 students $(16.0 \%)$ moderate motivation. The element of enthusiasm for learning and practicing has a mean value of 1.4 with a standard deviation of 2.21 consisting of 23 students (92.0\%) low motivation is 2 students $(8.0 \%)$ moderate level.

Apart from motivation, this study also measured the physical fitness elements achieved by students during the rounders game training. The following is the achievement of students' physical fitness which was measured after carrying out the rounders game using the TGfU learning model.

Indicators of the physical fitness test of students after following the TGfU teaching model in the rounders small ball game material in elementary school.

Table 2. Achievement of Students' Physical Fitness in the First Cycle

\begin{tabular}{llccc}
\hline No. & Indicator of IPFT & $\begin{array}{c}\text { Value of Likert } \\
\text { Sclae }\end{array}$ & TCR & Level \\
\hline $\mathbf{1}$ & Run 40 meters & 2.41 & 43.2 & Low \\
$\mathbf{2}$ & Pull up & 2.80 & 55.8 & Enough \\
$\mathbf{3}$ & Sit ups 30 seconds & 3.50 & 70.0 & Enough \\
$\mathbf{4}$ & Upright Jump & 2.37 & 42.1 & Low \\
$\mathbf{5}$ & Run 600 Meters & 1.54 & 19.2 & Low \\
\hline & Average & $\mathbf{2 . 5 2}$ & $\mathbf{4 6 . 1}$ & Low \\
\hline
\end{tabular}

Based on table two above, it shows that the average physical fitness of students after taking the IPFT-test through the learning process and rounders game training using the TGfU model in the Primary Schools of Padang Pariaman Regency is 2.52 with the respondent achievement stage (TCR) 46.1\%. This shows that the physical fitness achievements of students following the TGfU teaching model in the first cycle are still not optimal or still low.

This low achievement is probably due to the unfamiliarity of students with the TGfU learning model given in rounders game training in the field. In addition, students have not been trained to develop their cognitive abilities in discussing strategic and tactical development in mastering sports using the TGfU approach.

From the findings of this first cycle, the researcher asked each group to report the results of their work accompanied by their conclusions, and then the rounders game training activities were carried out in a row using the TGfU model followed by two groups. After reporting, there was input from Group one regarding the conclusions. According to them, the conclusions made by Group Two are still lacking because they are still 
only focused on the content of the students activities sheets, it is better to add information obtained from playing experience when developing tactical games.

Based on the observation data, it was obtained that the percentage of student learning motivation in the first cycle was in the low category and the physical fitness achievement was not optimal, namely 4.61 which was in the low category. So that the reflection stage in the first cycle reports the weaknesses or shortages of teachers during the implementation of learning activities due to limited learning and training time.

These weaknesses can be used as a reference so that they can be addressed at the next meeting, especially the problem of time allocation and students' readiness to compete in the rounders game. The final conclusion regarding the findings which are the weak points at this first cycle meeting is that students are still not optimally participating in all physical movement exercises instructed by the teacher, besides that the limited training time also greatly affects the low performance of students' rounders in the field.In the analysis of tactical abilities in the development of the TGfU game strategy given to the student worksheets, students are still fixated on the examples given in the worksheets, this has not been developed because of limited time in providing explanations about the development of rounders game strategies and students have not been able to analyze and build tactical themselves under the guidance of their teacher. One of them is the absence of examples that can be seen and observed by students over and over again to carry out strategy and tactical analysis in a game of rounders. Limited information, both from the teacher and from the results of group discussions in training activities, also affects student performance.

For this reason, in the second cycle, the teacher must be prepared with appropriate learning planning and time allocation in accordance with the material being taught by first providing material and physical exercise assignments to students at home with the aim that the available training time can be used effectively for mastery. Rounders learning materials, starting from tactical development, playing rounders game strategies to mastering the accuracy of throwing the ball, catching the ball, passing the ball, dodging ball movements and physical strengthening through physical exercises which are mostly done by students first at home by giving video of rounders game to students in order they can practice in at home and in the field before playing sports started.

\section{Second Cycle of Teaching}

The first meeting in this second cycle involved 25 fifth grade elementary students. In the initial activity the researcher tried to carry out learning with the basic material of the small ball game of rounders and carry out learning activities according to the learning scenario that had been prepared in the Learning Implementation Plan (RPP) that had been prepared. In the early stages the teacher conveys the learning objectives, rounders game techniques, strategy development and tactics in the rounders game. The purpose of this explanation is so that students can clearly understand the basic concepts of the renders game.

As in the first cycle, the researcher put forward the learning objectives and wrote them down on the blackboard. In addition to providing explanations on the blackboard, the teacher also played a rounderss ball game video that students could observe and learn together locally. Observations are made repeatedly so that students are trained to think of tactics and strategies in winning a rounderss game. In this way it is hoped that all students can pay more attention, note and observe movements and tactical development in building rounderss game strategies that can be explained by the teacher and easily understood by students in the classroom.

The teacher then motivates the students by explaining that one of the strategies to win the rounders competition is to improve physical fitness by diligently carrying out running exercises, pull ups, straight jumping, sit ups and others. This physical fitness exercise is very useful to increase the stamina of students following the rounders game with the TGfU model The teacher also provides instructions on how to do physical exercise correctly to students, so that students can do group exercises and help each other during physical exercise. Togetherness in group training in the field and the enthusiasm of the teacher to provide an example is very influential in increasing student motivation to participate in training and be actively involved in rounders matches in the field, by building motivation to become champions in every game.

After finishing delivering the rounders small ball game material and giving examples of correct physical exercises including practice catching the ball correctly, throwing the ball, hitting the ball and dodging movements while running, making students more interested in playing rounders coupled with physical exercises that are also built to strengthen student stamina to be more fit during the game later.

At the end of the session the teacher provides a written exercise using the student activity sheets which contains discussion assignments about the rounders game and asks representatives of each group to report the results of the discussion, and hopes that the reporter appointed by each group is a different member from the 
first cycle. The researcher appointed the first group to start reporting, and followed by the second and third groups, respectively. The results of the report show that students' understanding per group about the rounders game is not a problem and their answers indicate an increase in their understanding of the rounders game, an increase in the ability to build strategies and tactics in rounders games and increase their physical training required for rounders games.

From the results of learning activities, small ball game material of rounders and physical exercise in this second cycle showed an increase in students' motivation and their participating in learning and training conducted, one of which was because the teacher presented interesting and fun interactive videos that students could observe and learn simultaneously and repeatedly. They also can strengthen the skills and abilities to build strategy and tactical to win rounders game. The following are the results of students' motivation in the second cycle.

Based on Table 3, the motivation stages for elementary school students in Sungai Sariak of Padang Pariaman Regency to the element of motivation for interest in learning is 4.34 with a standard deviation of 2.84 consisting of 7 students $(28.0 \%)$ moderate level and 18 students $(72.0 \%)$ high level. Diligent and serious elements with 4.26 with a standard deviation of 3.02 consisting of 6 students $(24.0 \%)$ medium level and 19 students (76.0\%) high level. Meanwhile, the elements have a strong curiosity 4.32 with a standard deviation of 2.35 consisting of 2 students $(8.0 \%)$ at low level, 7 students $(28.0 \%)$ in medium stage and 16 people (64.0\%) at high level. In addition, the element of enthusiasm for learning and practice has an average score of 4.23 with a standard deviation of 2.19 . The results showed 8 students $(32.0 \%)$ were at the moderate level and 17 students $(68.0 \%)$ were at the high level.

Table 3. Students' Motivation in the Second Cycle of Teaching by using TGfU learning model

\begin{tabular}{lccccc}
\hline \multicolumn{1}{c}{ Motivation to learn } & \multicolumn{3}{c}{ Level } & Average & SD \\
\cline { 2 - 5 } & Low & Moderate & High \\
& $(0-2.5)$ & $(2.6-3.9)$ & $(4.0-5.0)$ & \\
\hline Interest to learn & - & $7(28.0 \%)$ & $18(72.0 \%)$ & 4.34 & 2.85 \\
Diligent and serious & - & $6(24.0 \%)$ & $19(76.0 \%)$ & 4.26 & 3.02 \\
Strong curiosity & $2(8.0 \%)$ & $7(28.0 \%)$ & $16(64.0 \%)$ & 4.32 & 2.35 \\
The spirit of learning and & - & $8(32.0 \%)$ & $17(68.0 \%)$ & 4.23 & 2.19 \\
practicing & & & & $\mathbf{4 . 2 9}$ & \\
\hline Average & & & & $\mathbf{2 . 6 0}$ \\
\hline
\end{tabular}

Following are the achievements of the student's physical fitness test after following the small ball game of rounders by using the TGfU model for fifth grade of elementary school students in this second cycle, the following results were obtained:

Table 4. Student's Physical Fitness Achievement In the Second Cycle

\begin{tabular}{llccc}
\hline No & \multicolumn{1}{c}{ Indicator of IPFT } & $\begin{array}{c}\text { Value of Likert } \\
\text { Sclae }\end{array}$ & TCR & Level \\
\hline $\mathbf{1}$ & Run 40 meters & 3.91 & 81.2 & Good \\
$\mathbf{2}$ & Pull up & 3.84 & 80.8 & Good \\
$\mathbf{3}$ & Sit ups 30 seconds & 4.25 & 83.8 & Good \\
$\mathbf{4}$ & Upright Jump & 3.22 & 79.2 & Good \\
$\mathbf{5}$ & Run 600 Meters & 3.47 & $\mathbf{7 9 . 5}$ & Good \\
\hline & Average & $\mathbf{3 . 7 4}$ & $\mathbf{7 6 . 9}$ & Good \\
\hline
\end{tabular}

Based on the data in table 4 above, it shows that the average value of physical fitness in the TGfU learning material of rounders games for elementary school student in Sungai Sariak of Padang Pariaman Regency is 3.74 with a respondent achievement level (TCR) of $76.9 \%$. This shows that the physical fitness achievement of students with the TGfU learning model is at a good level. The indicator of the Indonesian physical fitness test which was carried out on fifth grade elementary school students of Padang Pariaman Regency. Overall the physical fitness items measured obtained the value of likert scale of 3.74 were at a good level.

This high achievement was probably due to students getting accustomed to the TGfU learning model given in rounders game training in the field. In addition, students are also used to being trained as was done in the first cycle in developing their cognitive abilities and are getting used to discussing strategic and tactical development to be able to win in the rounders game. 
The results of this second cycle of learning indicate that each group is good and correct in carrying out physical training based on the Indonesian Physical Fitness Test and has been able to build rounders well during the games by using the TGfU model which is carried out in the school field. From these results, the researcher and all the students made conclusions related to the results of the discussion of the rounders small ball game learning activities that had been taught. Based on the observation data, the percentage of student motivation during the learning process was found to be in the very good category with an average Likert scale of 4.29 .

The results of researcher observations, the implementation of learning at the 3rd meeting was very good, so there was nothing that needed to be corrected. Students have become more active in doing physical exercises for 40 meters running, sit ups, straight jumps, pull ups and 600 meter runs. In addition to practicing, students are also diligent in discussing strategies and tactical development to win the rounders game which is carried out in the TGfU learning model.On the other hand, seen from the results of the work of each group in completing the student worksheets given were also very good. This indicates that learning activities have succeeded in increasing students' learning motivation and at the same time increasing their physical fitness optimally through rounders games using the TGfU approach.

Observations made to observe the development of student performance were carried out with the aim of knowing the mastery of the concept of small ball game material, especially mastery of ball hitting techniques, catching the ball, throwing the ball, dodging ball techniques when running and supporting physical training techniques such as 40 meter running techniques, sit ups techniques, pull up techniques, upright jumping techniques and 600 meter running techniques. This observation is carried out during the learning process. This observation was carried out with the aim of knowing the students' mastery of tactical concepts and strategies for the ronders ball game that the students carried out during the rounderss competition using the TGfU model developed by the teacher.

There are four important things that researchers get from the results of observations on student performance, namely students are motivated to take part in rounders game training activities if given a video that they can observe and learn over and over, then students are highly motivated if rounders game exercises are carried out using a game model like a match is held. In this case the teacher succeeded in implementing the TGfU learning model properly which could increase student motivation and student fitness to develop tactical and game strategies and especially physical strengthening of students to be more fit and endure during rounders game matches held in the field.Learning sports based on games on small ball game material is very appropriate to use the TGfU learning model (Batez, Petrušič , Bogataj, \& Trajković , 2021; Gaspar, Gil-Arias, Del Villar, Práxedes, \& Moreno, 2021). By applying this model the teacher succeeded in increasing the students' motivation and physical fitness for the better in the second cycle. This success is due to the fact that the TGfU learning model in its implementation is more holistic by combining learning approaches, games, training and cognitive strengthening (Hernando-Garijo, Hortigüela-Alcalá, Sánchez-Miguel, \& GonzálezVíllora, 2021). The success of the TGfU learning model can certainly be used as the best model for sports education teachers to carry out the teaching and learning process of physical education in elementary schools in Padang Pariaman Regency. Because this TGfU learning model has advantages, among others, this model can be used as a model that can increase the achievement of students' motivation and physical fitness. This model can also improve student achievement.

\section{Implications}

Learning sports based on games on small ball game material is very appropriate to use the TGfU learning model. By applying this model the teacher succeeded in increasing the students' motivation and physical fitness for the better in the second cycle. This success is due to the fact that the TGfU learning model in its implementation is more holistic by combining learning approaches, games, training and cognitive strengthening. The success of the TGfU learning model can certainly be used as the best model for sports education teachers to carry out the teaching and learning process of physical education in elementary schools in Padang Pariaman Regency. Because this TGfU learning model has advantages, among others, this model can be used as a model that can increase the achievement of students' motivation and physical fitness. This model can also improve student achievement.

\section{Conclusions}

From the results and discussion it can be concluded that the TGfU learning model can be used as the best model in increasing student learning motivation to do physical exercise and student motivation to take part in the rounders game using the TGfU model which is interesting and fun for students. As a tactical and strategybased model, this model is certainly still more complete in addition to increasing students' motivation and 
their physical fitness it can also improve students' cognitive abilities in developing strategies and tactics in a sports game to win a competition in the rounders game.

\section{References}

Alcalá, D. H., \& Garijo, A. H. (2017). Teaching games for understanding: A comprehensive approach to promote student's motivation in physical education. Journal of human kinetics, 59, 17.

Batez, M., Petrušič , T., Bogataj, Š., \& Trajković , N. (2021). Effects of Teaching Program Based on Teaching Games for Understanding Model on Volleyball Skills and Enjoyment in Secondary School Students. Sustainability, 13(2), 606.

Chiva-Bartoll, O., \& Fernández-Rio, J. (2021). Advocating for Service-Learning as a pedagogical model in Physical Education: towards an activist and transformative approach. Physical Education and Sport Pedagogy, 12(1), 1-14.

Chiva-Bartoll, O., Maravé-Vivas, M., Salvador-García, C., \& Valverde-Esteve, T. (2021). Impact of a Physical Education Service-Learning programme on ASD children: A mixed-methods approach. Children and Youth Services Review, 126, 106008.

Dimas, M. A., Galway, S. C., \& Gammage, K. L. (2021). Do you see what I see? The influence of selfobjectification on appearance anxiety, intrinsic motivation, interoceptive awareness, and physical performance. Body Image, 39, 53-61.

Ferkins, L., Shilbury, D., \& McDonald, G. (2005). The role of the board in building strategic capability: Towards an integrated model of sport governance research. Sport Management Review, 8(3), 195-225.

García-Castejón, G., Camerino, O., Castañer, M., Manzano-Sánchez, D., Jiménez-Parra, J. F., \& ValeroValenzuela, A. (2021). Implementation of a Hybrid Educational Program between the Model of Personal and Social Responsibility (TPSR) and the Teaching Games for Understanding (TGfU) in Physical Education and Its Effects on Health: An Approach Based on Mixed Methods. Children, 8(7), 573.

Gaspar, V., Gil-Arias, A., Del Villar, F., Práxedes, A., \& Moreno, A. (2021). How TGfU Influence on Students' Motivational Outcomes in Physical Education? A Study in Elementary School Context. International Journal of Environmental Research and Public Health, 18(10), 5407.

Gil-Arias, A., Harvey, S., Cárceles, A., Práxedes, A., \& Del Villar, F. (2017). Impact of a hybrid TGfU-Sport Education unit on student motivation in physical education. PloS one, 12(6), e0179876.

Gil-Arias, A., Harvey, S., García-Herreros, F., González-Víllora, S., Práxedes, A., \& Moreno, A. (2021). Effect of a hybrid teaching games for understanding/sport education unit on elementary students' selfdetermined motivation in physical education. European Physical Education Review, 27(2), 366-383.

Heemsoth, T., Boe, L., Bükers, F., \& Krieger, C. (2020). Fostering pre-service teachers' knowledge of 'teaching games for understanding'via video-based vs. text-based teaching examples. Physical Education and Sport Pedagogy, 1-14.

Hellison, D. (2010). Teaching personal and social responsibility through physical activity. New York: Palgrave Macmillan.

Hernando-Garijo, A., Hortigüela-Alcalá, D., Sánchez-Miguel, P. A., \& González-Víllora, S. (2021). Fundamental Pedagogical Aspects for the Implementation of Models-Based Practice in Physical Education. International Journal of Environmental Research and Public Health, 18(13), 7152.

Holt, N. L., Strean, W. B., \& Bengoechea, E. G. (2002). Expanding the teaching games for understanding model: New avenues for future research and practice. Journal of teaching in Physical Education, 21(2), $162-176$.

Hopper, T., \& Kruisselbrink, D. (2002). Teaching Games for Understanding: What does it look like and how does it influence student skill learning and game performance. AVANTE, July, 1-29.

Huberman, M., \& Miles, M. B. (2002). The qualitative researcher's companion: Sage.

Jarrett, K., Eloi, S., \& Harvey, S. (2014). Teaching Games for Understanding (TGfU) as a positive and versatile approach to teaching adapted games. European Journal of Adapted Physical Activity, 7(1), 6-20.

Karisman, V. A. (2021). Physical Education And Game-Based Approach: An Attempt To Improve Basic Move Skills. Turkish Journal of Computer and Mathematics Education (TURCOMAT), 12(10), 62686272.

Kunlasomboon, N., Wongwanich, S., \& Suwanmonkha, S. (2015). Research and development of classroom action research process to enhance school learning. Procedia-Social and Behavioral Sciences, 171, 13151324.

López-Pastor, V. M., Kirk, D., Lorente-Catalán, E., MacPhail, A., \& Macdonald, D. (2013). Alternative assessment in physical education: a review of international literature. Sport, Education and Society, 18(1), 57-76. 
Luguetti, C., \& McDonald, B. (2021). Towards a pedagogy of love in health and physical education. Critical Pedagogies in Physical Education, Physical Activity and Health.

MacPhail, A., Kirk, D., \& Griffin, L. (2008). Throwing and catching as relational skills in game play: Situated learning in a modified game unit. Journal of teaching in Physical Education, 27(1), 100-115.

Ní Chróinín, D., \& Cosgrave, C. (2013). Implementing formative assessment in primary physical education: teacher perspectives and experiences. Physical Education and Sport Pedagogy, 18(2), 219-233.

Nyberg, G., \& Larsson, H. (2014). Exploring 'what'to learn in physical education. Physical Education and Sport Pedagogy, 19(2), 123-135.

Reflianto, R., \& Syamsuar, S. (2017). Integrated Learning Model as The Best Practice on Physical Fitness.

Roberts, W. M., Newcombe, D. J., \& Davids, K. (2019). Application of a constraints-led approach to pedagogy in schools: Embarking on a journey to nurture physical literacy in primary physical education. Physical Education and Sport Pedagogy, 24(2), 162-175.

Samodra, T. J. (2021). Pemahaman Konsep Bermain Siswa Motorik Tinggi Dan Rendah Dengan Model Pembelajaran Teaching Game For Undertanding (TGFU). Jurnal Ilmu Keolahragaan Undiksha, 8(2), 117-126.

Stork, S., \& Sanders, S. W. (2008). Physical education in early childhood. The Elementary School Journal, 108(3), 197-206.

Sudirman, J. (2021). Teaching Values Through Sports Science From Elementary Level To Higher Education: A Case Of Makassar Indonesia. Annals of the Romanian Society for Cell Biology, 13154-13163. 